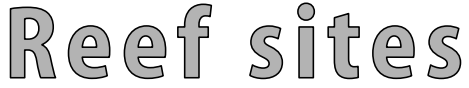

\section{Juvenile batfish hidden in seagrass}

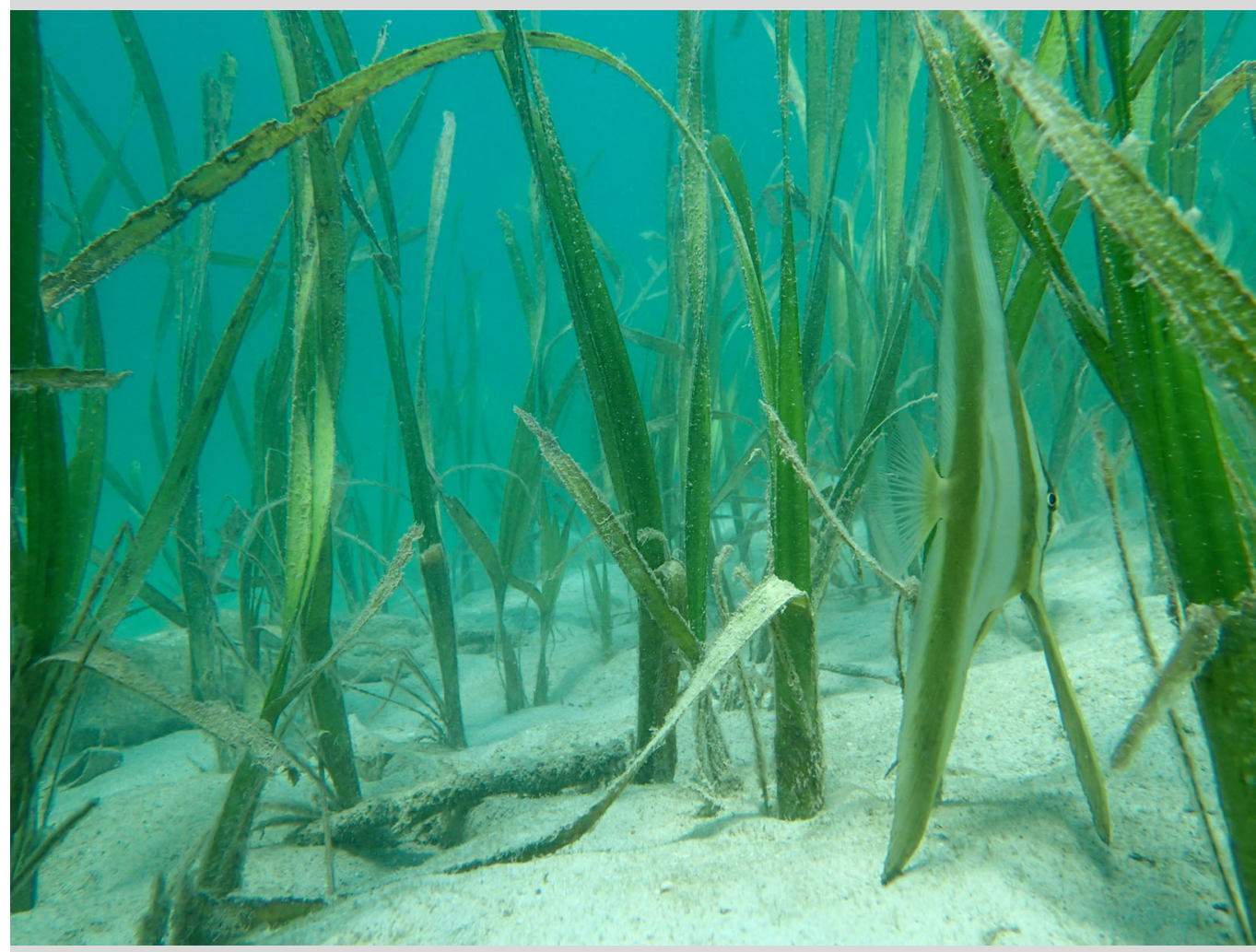

Fig. 1 Juvenile batfish (Platax teira) in Enhalus acoroides, Barrang Lompo, Spermonde Islands, South Sulawesi, Indonesia
Juvenile batfishes in the genus Platax (Ephippidae) are known to have striking coloration that is considered to be protective (Randall 2005). Juvenile IndoPacific $P$. teira and $P$. orbicularis have broad dark and silver vertical bands. This coloration contrasts sharply with blue waters and resembles, at least to the human eye, floating debris or seaweed, cages, mooring lines, shipwrecks, and aspects of other habitats where they typically occur. We found Platax teira (longfin batfish) consistently occur-

ring in a shallow bed of the seagrass Enhalus acoroides on Barrang Lompo, one of the many Spermonde islands off South Sulawesi, Indonesia. Their color banding provides virtually no contrast against the seagrass. Seagrass might provide very good habitat for juvenile batfish, although we have found no published reports of juvenile batfishes in seagrass beds. Juvenile batfishes are both herbivorous and carnivorous (Barros et al. 2013); in seagrass, they would have abundant plant food and their coloration could conceal them from either their prey or predators. Herbivory by juvenile batfish hidden in seagrass might help reduce deleterious epiphytes that bloom on seagrasses in the face of coastal eutrophication (Fig. 1).

Open Access This article is distributed under the terms of the Creative Commons Attribution License which permits any use, distribution, and reproduction in any medium, provided the original author(s) and the source are credited.

\section{References}

Barros B, Sakai Y, Hashimoto H, Gushima K, Oliveira Y, Abrunhosa FA, Marcelo Vallinoto M (2013) Are ephippid fish a "sleeping functional group"? Herbivory habits by four Ephippidae species based on stomach contents analysis. In: Barros B, Fernandes MEB (eds) Herbivory. InTech, Rijeka, Croatia, pp 33-46 Randall JE (2005) A review of mimicry in marine fishes. Zool Studies 44:299-328

S. L. Williams $(\bowtie) \cdot J$. Abbott $\cdot$ G. Ha

Bodega Marine Laboratory, University of California at Davis, Bodega Bay, CA 94923, USA

e-mail: slwilliams@ucdavis.edu

R. Ambo-Rappe

Faculty of Marine Science and Fisheries, Hasanuddin University, Makassar, Sulawesi, Indonesia

Received: 11 May 2014/Accepted: 24 July 2014/Published online: 3 August 2014

Coral Reefs (2014) 33:909

(C) The Author(s). This article is published with open access at Springerlink.com 2014 DOI 10.1007/s00338-014-1194-6 